\title{
A developmental study of rat sperm and testis selenoproteins
}

\author{
H. I. Calvin*, K. Grosshans, S. R. Musicant-Shikora and S. I. Turner \\ Department of Genetics and Development and Center for Reproductive Sciences, \\ Columbia University College of Physicians and Surgeons, 630 West 168th Street, New York, \\ NY 10032, U.S.A.
}

\begin{abstract}
Summary. Essentially all of the selenium in the rat spermatozoon is bound to a polypeptide of $M_{\mathrm{r}} 15000-17000$ confined to the capsule that surrounds the sperm mitochondria. Isoelectric focussing of isolated ${ }^{75} \mathrm{Se}$-labelled, carboxymethylated mitochondrial capsule protein (MCP) reveals the presence of at least four radioactive components, with a predominant charge isomer at $\mathrm{pI} 4 \cdot 6$. The sperm selenoprotein appears to be identical with $\mathrm{MCP}$, as judged by the exact coincidence of radioactivity and protein stain during two-dimensional electrophoresis.

The temporal pattern of ${ }^{75} \mathrm{Se}$-labelling of rat caput epididymal spermatozoa after intratesticular ${ }^{75} \mathrm{Se}$ injection suggests that maximum incorporation of ${ }^{75} \mathrm{Se}$ into MCP occurs in step 7-step 12 spermatids and that ${ }^{75} \mathrm{Se}$ uptake ceases during step 15 of spermiogenesis. The developmental appearance of sperm selenoprotein in rat testis therefore appears to lag several days behind that reported for MCP in mouse testis, suggesting the presence of selenium-free MCP in immature germ cells. SDS gel electrophoretic analysis of testis subcellular fractions $24 \mathrm{~h}$ after ${ }^{75} \mathrm{Se}$ injection into rat testis at 21,28 and 90 days of age indicates that sperm selenoprotein first appears in very low concentration during late meiosis and that its concentration increases sharply during early spermiogenesis. Additional ${ }^{75} \mathrm{Se}$-labelled polypeptides were detected on the gels, most of them of higher molecular weight than MCP. At least two of these $\left(M_{\mathrm{r}} 47000\right.$ and 54000 ) displayed a marked decrease in labelling between 5 and $24 \mathrm{~h}$ after injection into adult testis, coincident with a comparable increase in ${ }^{75} \mathrm{Se}$-labelled MCP, indicating that they may be precursors of MCP.
\end{abstract}

\section{Introduction}

The effects of selenium deficiency upon spermatogenesis have been well characterized in rats and mice. The first change observed is abnormal development of the sperm midpiece (Wu et al., 1973, 1979; Calvin et al., 1981a; Wallace et al., 1983a). As the period of Se deficiency is prolonged, disorganization of the mitochondrial sheath, the structure which defines the midpiece region of the spermatozoon, becomes more pronounced. Eventually, this results in reduced sperm motility in the mouse (Wallace et al., 1983a) or immotility in the rat (Wu et al., 1973). In addition, the level of sperm production is reduced and testicular size decreases (Wallace et al., 1983a). Isolation of SDSinsoluble mitochondrial ghosts from control and Se-deficient rats and mice and examination of negatively-stained whole mounts has revealed that Se-deficient ghosts are smaller, less curved and more fragile than those of controls (Wallace et al., 1983b), thus offering a possible explanation for the reduced stability of the mitochondrial sheath in the Se-deficient rodent spermatozoon.

The biochemical locus of Se in the rat spermatozoon is a single fibrous protein of $M_{\mathrm{r}} 15000-17000$ (Calvin, 1978; McConnell et al., 1979). This molecule, which is apparently vital for the maintenance of normal mitochondrial stability and configuration, has been shown in the bull and the rat to be the major component of the keratinous capsule which surrounds the sperm mitochondrion (Pallini

\footnotetext{
*Present address: Department of Biochemistry and Nutrition, Virginia Polytechnic Institute and State University,
} Blacksburg, VA 24061, U.S.A. 
\& Bacci, 1979; Calvin et al., 1981b). It has therefore been designated as mitochondrial capsule protein (MCP) (Calvin et al., 1981b). The amino acid composition of bovine MCP includes very high percentages of cysteine and proline and a relatively low content of hydrophobic residues (Pallini et al., 1979).

Tracer studies with ${ }^{75} \mathrm{Se}$ have demonstrated that $\mathrm{Se}$ is localized within the midpiece of the spermatozoon (Brown \& Burk, 1973) and is essentially confined to MCP (Calvin et al., 1981b). Such investigations have also revealed the presence of additional labelled proteins in the testis of several species (Prohaska et al., 1977; McConnell et al., 1979; Pond et al., 1983). The function of these other testicular selenoproteins remains obscure. The timing of ${ }^{75} \mathrm{Se}$ incorporation into the sperm selenoprotein has been estimated for the mouse (Gunn et al., 1967), rat (Gunn \& Gould, 1970), bull (Smith et al., 1979) and ram (Pond et al., 1983). It is generally agreed that incorporation ceases before the maturation phase of spermiogenesis. However, the stage in which Se uptake first occurs is unclear, as is the timing of maximal Se incorporation.

In this study we have used a combination of methods to delineate more precisely the developmental pattern of Se incorporation during spermatogenesis in the rat, and to confirm that sperm selenoprotein and MCP are identical.

\section{Materials and Methods}

Animals. Male Sprague-Dawley rats were purchased from CAMM Laboratories (Wayne, NJ), at 0-1 or at 60-90 days of age.

Reagents. Sodium dodecyl sulphate (SDS) and acrylamide were purchased from National Diagnostics (Somerville, $\mathrm{NJ}$ ). $N, N^{\prime}$-methylene bisacrylamide was from Kodak Laboratories (Rochester, NY). Unless otherwise specified, all other chemicals used were analytical grade reagents, purchased from Fisher Scientific (Springfield, NJ) or from Sigma Chemical Co. (St Louis, MO).

Incorporation of ${ }^{75}$ Se into caput epididymal spermatozoa. ${ }^{75} \mathrm{Se}$-labelled selenite (sp. act. $105 \mathrm{mCi} / \mathrm{mg}$ ) was received from NEN Research (Boston, MA) and diluted to a concentration of $120 \mu \mathrm{Ci} / \mathrm{ml}$ in $0.05 \mathrm{M}$-Tris- $\mathrm{HCl}, \mathrm{pH} 7 \cdot 5 / 0 \cdot 10 \mathrm{M}$ $\mathrm{NaCl}$ (TBS). Bilateral intratesticular injections of $12 \mu \mathrm{Ci} /$ testis $(0 \cdot 10 \mathrm{ml})$ were administered to 60 -day-old $250-300 \mathrm{~g}$ male rats, followed $24 \mathrm{~h}$ later by an intraperitoneal injection of $0.25 \mu \mathrm{mol} \mathrm{Se}$ (as sodium selenite) $/ 100 \mathrm{~g}$ body weight. The animals were killed in groups of three at $6,7,8,9,10,12,14,16,18,21,28,35,42$ or 49 days after injection. Spermatozoa were expressed separately from each caput epididymidis and were separated from aggregates of epididymal cells by differential centrifugation (Calvin et al., 1973). Specific activities of each sperm sample (c.p.m./10 spermatozoa) were determined by assay of radioactivity with a liquid scintillation spectrometer and counting of spermatozoa with a haemocytometer (Calvin, 1981). Approximate efficiency of assay of ${ }^{75} \mathrm{Se}$ was $45 \%$. Corrections were made for decay of ${ }^{75} \mathrm{Se}$ during the course of the experiment and for slight variations in counting efficiency with the aid of standards of ${ }^{75}$ Se-labelled selenite.

Labelling of testicular proteins. ${ }^{75} \mathrm{Se}$-labelled selenite (sp. act. $512 \mathrm{mCi} / \mathrm{mg}$ ), diluted to a concentration of $1000 \mu \mathrm{Ci} /$ $\mathrm{ml}$ in TBS, was administered by unilateral intratesticular injection into 3 males at each of the following ages: 21 days $(50 \mu \mathrm{Ci} /$ testis $), 28$ days $(50 \mu \mathrm{Ci} /$ testis $)$ and 90 days $(100 \mu \mathrm{Ci} /$ testis $)$. The animals were killed $24 \mathrm{~h}$ after injection by cervical dislocation under ether anaesthesia. In addition, two 90 -day-old rats were injected intratesticularly and killed $5 \mathrm{~h}$ after injection. The injected testes were removed, weighed, and immediately homogenized in five volumes of $20 \mathrm{~mm}$-Tris- $\mathrm{HCl}, \mathrm{pH} 7.5 / 1 \mathrm{~mm}$-EDTA/0.1 mM-phenylmethylsulphonyl fluoride. The testicular weights at each age were $0.10-0.12 \mathrm{~g}$ at 22 days, $0.32-0.42 \mathrm{~g}$ at 29 days and $1.7-1.8 \mathrm{~g}$ at 90 days. The contralateral (non-injected) testes of the immature rats were fixed in Helly's solution and processed for staining with the Feulgen agent by standard techniques (Lillie \& Fullmer, 1976), to confirm previous information about germ cell composition at these ages.

The homogenate of each radioactive testis was centrifuged at $800 \mathrm{~g}$ for $15 \mathrm{~min}$. The resulting supernatant was centrifuged at $15000 \mathrm{~g}$ for $15 \mathrm{~min}$. The residues obtained at $800 \mathrm{~g}(\mathrm{R})$ and $15000 \mathrm{~g}(\mathrm{r})$ were washed by resuspension in homogenization buffer and recentrifugation. The washed residues, $R$ and $r$, were then dispersed by pipetting and sonication in $1 \% \mathrm{SDS} / 0.05 \mathrm{M}$-Tris-HCl, pH 7.5/5\% mercaptoethanol (Buffer DTM). The two residues and the $15000 \mathrm{~g}$ supernatant fraction (s) were stored at $-70^{\circ} \mathrm{C}$ and were analysed electrophoretically by SDS gel electrophoresis within $1-4$ weeks.

SDS gel electrophoresis. Slab gel electrophoresis was carried out in the system of Laemmli (1970), using a uniform $10 \%$ or $12.5 \%$ acrylamide separating gel and a $5 \%$ acrylamide stacking gel. The slab gels were fixed in $50 \%$ trichloroacetic acid and stained with Coomassie Blue R, as described by Hecht \& Bradley (1981). After enclosure in cellulose dialysis membranes, the gels were dehydrated with a slab gel dryer (Shadel Instruments, San Francisco, CA) and photographed through a yellow filter. Autoradiographic localization of radioactive polypeptides was carried out by incubation at $-70^{\circ} \mathrm{C}$ with Kodak XAR-5 X-ray film in the presence of a Quanta III intensifying screen (Dupont, Wilmington, DE). 


\begin{abstract}
${ }^{75}$ Se-labelled mitochondrial capsule protein $(M C P) .{ }^{75} \mathrm{Se}$-labelled selenite (sp. act. $105-512 \mu \mathrm{Ci} / \mathrm{mg}$ ) was diluted to a concentration of $1000 \mu \mathrm{Ci} / \mathrm{ml}$ in TBS. A dose of $100 \mu \mathrm{Ci} /$ testis $(0.1 \mathrm{ml})$ was injected bilaterally into the testes of 60-day-old rats. At 21-23 days after injection, the animals were killed and spermatozoa were expressed from the cauda epididymidis. Sperm mitochondrial capsules were then isolated by the procedure previously described (Calvin et al., 1981b). Their degree of purity with respect to mitochondrial capsule protein was established by SDS gel electrophoresis. The radioactive mitochondrial capsule preparations were, in some experiments, diluted with unlabelled mitochondrial capsule protein (MCP), prepared similarly.
\end{abstract}

Carboxymethylation of $M C P$. Solutions of ${ }^{75} \mathrm{Se}$-labelled or unlabelled mitochondrial capsule protein in Buffer DTM were dialysed overnight against water and lyophilized. The residue was dissolved in $4 \cdot 0 \mathrm{M}$-guanidine $\mathrm{HCl} / 0 \cdot 2 \mathrm{M}$ Tris- $\mathrm{HCl}, \mathrm{pH} 8.1 / 5 \mathrm{~mm}$-dithiothreitol $/ 1.0 \mathrm{~mm}$-EDTA. After incubation for $10 \mathrm{~min}$ at room temperature, the solution was diluted with a $1 / 20$ volume of $0 \cdot 3 \mathrm{M}$-iodoacetic acid. Samples of the reaction mixture were assayed for $-\mathrm{SH}$ at 2-min intervals with 5,5'-dithiobis(2-nitrobenzoic acid) (Ellman, 1959). When-SH was no longer detectable (typically within $10 \mathrm{~min}$ ), unreacted iodoacetic acid was inaçtivated with an excess of dithiothreitol. The reaction mixture was frozen overnight at $-70^{\circ} \mathrm{C}$ before dialysis or was dialysed immediately against $0.01 \mathrm{M}-\mathrm{Tris}-\mathrm{HCl}, \mathrm{pH} 7 \cdot 5 / 1.0 \mathrm{mM}$-EDTA. Aliquants of the resulting solution were lyophilized and resuspended in Buffer DTM before SDS gel electrophoresis or in lysis buffer (O'Farrell, 1975) before isoelectric focussing.

Isoelectric focussing and two-dimensional gel electrophoresis. ${ }^{75} \mathrm{Se}$-labelled and unlabelled samples judged to contain at least $95 \%$ MCP by SDS gel electrophoresis were mixed to test the electrophoretic congruity of ${ }^{75} \mathrm{Se}$-labelled sperm protein and MCP. The procedure of O'Farrell (1975) for isoelectric focussing was modified as follows: (1) gel composition was altered by reducing urea content to $6.0 \mathrm{M}$ and including only $\mathrm{pH} 3$ to 10 ampholines (BioRad, Richmond, CA), (2) anode electrode solution was $1 \% \mathrm{H}_{2} \mathrm{SO}_{4}$ instead of $0.01 \mathrm{M}-\mathrm{H}_{3} \mathrm{PO}_{4}$, (3) cathode electrode solution was $1 \%$ ethanolamine instead of $0.02 \mathrm{M}-\mathrm{NaOH}$, (4) there was no pre-electrophoresis of gels, (5) the samples were applied at the acidic rather than the basic end of the gels. After 16-18 h of electrophoresis at $400 \mathrm{~V}$, the gels were: (1) stained for protein content (Otavsky \& Drysdale, 1975), (2) drained of excess buffer, wrapped in Saran wrap and frozen at $-20^{\circ} \mathrm{C}$, before analysis of ${ }^{75} \mathrm{Se}$ distribution, or (3) frozen at $-20^{\circ} \mathrm{C}$ in SDS gel electrophoresis sample buffer (O’Farrell, 1975) for 1-7 days.

To evaluate ${ }^{75} \mathrm{Se}$ distribution, isoelectric focussing gels frozen for 1-14 days were sectioned with a slicer consisting of parallel razor blades (BioRad, Richmond, CA), precooled to $-20^{\circ} \mathrm{C}$ to prevent thawing of the gel before slicing. The slices were transferred to culture tubes and assayed for radioactivity with a gamma counter (Nuclear Chicago, Model 1185 ) at approximately $40 \%$ counting efficiency.

SDS gel electrophoresis in the second dimension was performed in gels of uniform $10 \%$ or $12.5 \%$ acrylamide content. The isoelectric focussing gels were loaded without prior equilibration in sample buffer. Ampholines were selectively eluted by pre-electrophoresis at $10 \mathrm{~mA}$ for $20 \mathrm{~min}$ in the presence of $2 \%$ SDS running buffer in the upper reservoir (O'Farrell, 1975). Electrophoressis was then continued in the presence of $0.1 \%$ SDS at $150 \mathrm{~V}$ for $3 \mathrm{~h}$.

\title{
Results
}

\section{Characterization of radioactive sperm selenoprotein}

To investigate the possible microheterogeneity of the rat sperm selenoprotein and confirm its identity with MCP, mitochondrial ghosts were isolated from rats injected intratesticularly with ${ }^{75} \mathrm{Se}$-labelled selenite $21-25$ days before harvesting of cauda epididymal spermatozoa. The labelled residue, when dissolved and submitted to SDS gel electrophoresis, consisted almost entirely of a single polypeptide $\left(M_{\mathrm{r}} 16000\right)$, as noted previously (Calvin et al., 1981b).

After mixture with unlabelled mitochondrial capsules and carboxymethylation of - $\mathrm{SH}$ groups, the labelled protein was analysed by isoelectric focussing and radioactive assay of $1-\mathrm{mm}$ slices of unstained gels. A predominant peak (B) was observed at pI 4.6 (Fig. 1a). Minor variants were noted at values of $4 \cdot 5,4 \cdot 7$ and $4 \cdot 9$. Stained gels displayed a high background due to the persistence of ampholines (Otavsky \& Drysdale, 1975). However, a strong band proven to be radioactive upon subsequent elution was consistently noted in a position corresponding to pI 4.6 (Fig. Ib). In addition, a minor component at $\mathrm{pI} 4.7$ was present. It coincided approximately with peak $\mathrm{C}$ in the sliced, unstained gel (Fig. 1a). Manual sectioning of stained gels verified that the two bands at pI 4.6 and 4.7 were radioactive, whereas the space between them was essentially devoid of radioactivity. Two-dimensional electrophoresis and autoradiography of stained gels confirmed that the major variant of ${ }^{75} \mathrm{Se}$-labelled protein was electrophoretically identical with MCP (Figs $2 \mathrm{a}$ and $2 \mathrm{~b}$ ). 
(a)

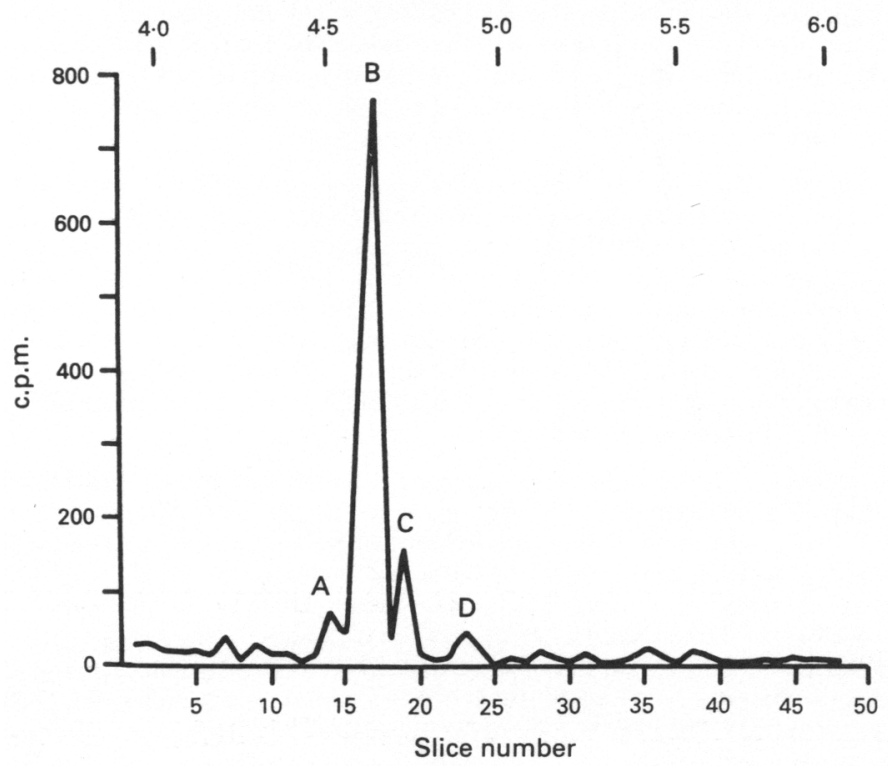

(b)

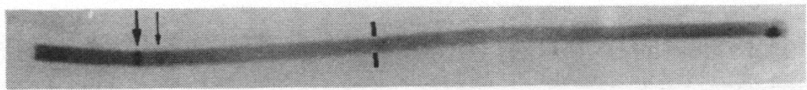

Fig. 1. Isoelectric focussing of ${ }^{75} \mathrm{Se}-$ labelled MCP. (a) Net c.p.m. detected in 1-mm slices of unstained column gel (Nos 1-48). Four significant peaks were seen (A-D). A pooled assay of the remaining slices (Nos 49-112) contained <10 c.p.m. above background (70 c.p.m.). (b) Stained gel. Larger arrow indicates position of MCP; smaller arrow indicates minor polypeptide component, probably corresponding to peak $\mathrm{C}$ in assay of radioactive slices. Broken line marks approximate position corresponding to slice No. 50 .

Fig. 2. Two-dimensional electrophoresis of ${ }^{75} \mathrm{Se}$-labelled MCP. Slab gel contained $12 \cdot 5 \%$ acrylamide. (a) Stained gel. The single spot equivalent to $M_{\mathrm{r}} 16000$ is MCP. Photo was cropped at rear end of a heavily stained band of eluted ampholines (arrow). (b) Autoradiogram. An aliquant containing 6200 c.p.m. was applied to gel. Autoradiogram was incubated for $24 \mathrm{~h}$ at $-70^{\circ} \mathrm{C}$. 


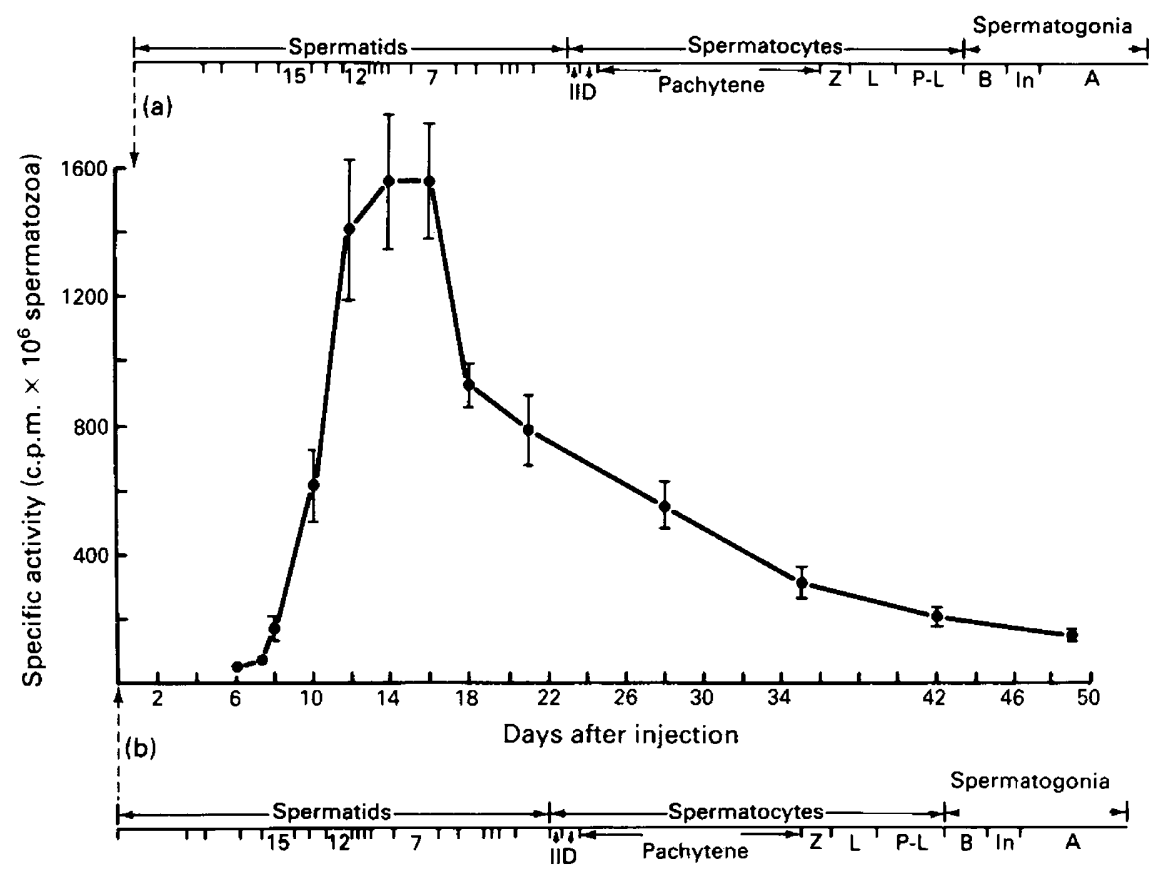

Fig. 3. Temporal pattern of ${ }^{75} \mathrm{Se}$ labelling in spermatozoa isolated from the caput of the rat epididymis after intratesticular injection of $\left[{ }^{75}\right.$ Se]selenite. Scales above and below graph indicate length and sequence of development stages in 52-day cycle of spermatogenesis in the Sprague-Dawley rat, as described by Clermont \& Harvey (1965). Interpretation of symbols: A (types $\mathrm{A}_{0}-\mathbf{A}_{4}$ spermatogonia); In (intermediate spermatogonia); $\mathbf{B}$ (type $\mathbf{B}$ spermatogonia); P-L (preleptotene spermatocytes); D (diplotene spermatocytes); II (secondary spermatocytes plus dividing meitoic cells); 7, 12 and 15 (steps of spermiogenesis). Placement of upper and lower developmental scales starting at 1 day (a) or 0 days (b) after injection selects respectively for the interval required for incorporated isotope to reach the midpoint or the initial segment of the caput epididymidis, as discussed in text.

Incorporation of ${ }^{75}$ Se into spermatozoa

By comparing ${ }^{75} \mathrm{Se}$ levels in caput epididymal spermatozoa isolated at various intervals after intratesticular administration of ${ }^{75} \mathrm{Se}$-labelled selenite, it has been possible to estimate the timing of both peak and final ${ }^{75} \mathrm{Se}$ incorporation into MCP during spermatogenesis. Figure 3 shows that the highest concentrations of ${ }^{75} \mathrm{Se}$ were observed between 12 and 16 days after injection. To evaluate the significance of this peak incorporation, a scale based on the data of Clermont \& Harvey (1965) for the duration of stages of spermatogenesis in the Sprague-Dawley rat has been placed above the graph, beginning at Day 1 (Fig. 3a). This assumes that spermatozoa require 1 day to reach the midpoint of the caput segment excised for the assay of ${ }^{75} \mathrm{Se}$-labelled spermatozoa (English \& Dym, 1982). Comparison of the scale with the graph indicates that peak incorporation of ${ }^{75} \mathrm{Se}$ occurred between steps 7 and 12 of spermiogenesis.

Placement of the same scale coincident with Day 0 below the graph (Fig. 3b) allows estimation of the minimum number of days required for the injected label to appear in spermatozoa which have just entered the initial segment of the caput epididymidis. This interval of 7-8 days reveals that incorporation of ${ }^{75} \mathrm{Se}$ must have ceased before step 16 of spermiogenesis. 


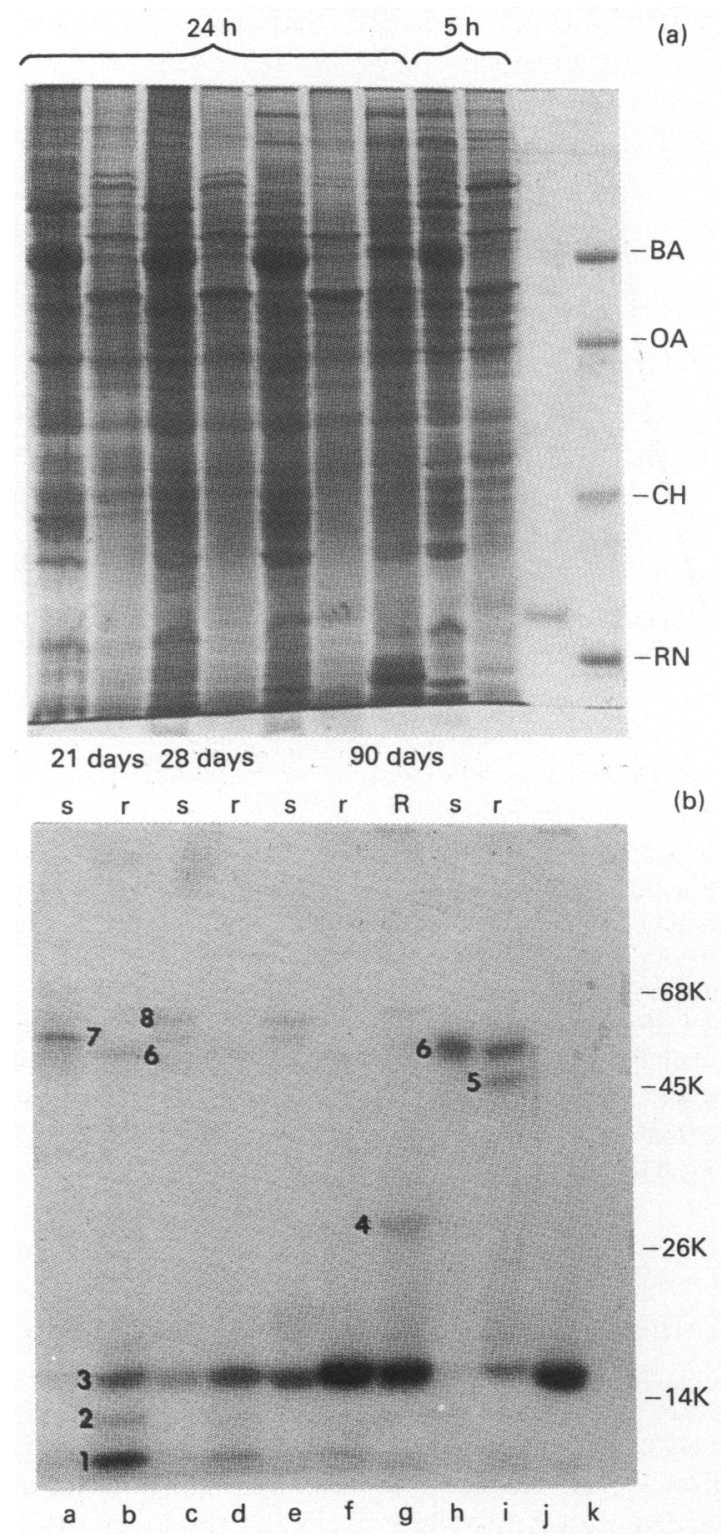

Fig. 4. SDS gel electrophoresis of labelled testis fractions $S, r$ and $R$ (see text) obtained after intratesticular injection of ${ }^{75} \mathrm{Se}$ into male Sprague-Dawley rats at 21 (lanes a \& b), 28 (lanes $\mathrm{c} \&$ d) and 90 (lanes e-i) days of age (10\% acrylamide gel). (a) Stained gel. (b) Autoradiogram (72-h incubation). The testes were removed at $24 \mathrm{~h}$ or $5 \mathrm{~h}$ after injection, as indicated. ${ }^{75} \mathrm{Se}$-labelled MCP (lane j) and four molecular weight standards (lane $\mathbf{k}$ ) were electrophoresed in parallel with the rat testis proteins. The non-radioactive standards were: bovine serum albumin (BA) (Sigma), ovalbumin (OA) (Cooper Biomedical, Malvern, PA), bovine chymotrypsinogen ( $\mathrm{CH})$ (Cooper) and bovine ribonuclease A (RN) (Cooper). $M_{\mathrm{r}} \times 10^{-3}$ of these standards is indicated in (b). Estimated values of $M_{\mathrm{r}} \times 10^{-3}$ for labelled testis selenopolypeptides (bands 2-8) are: 13 (band 2), 16 (band 3), 28 (band 4), 47 (band 5), 54 (band 6), 58 (band 7), 63 (band 8). 
The levels of radioactivity in caput spermatozoa decreased gradually between 18 and 50 days after injection. This is consistent with the possibility that meiotic and even pre-meiotic germ cells incorporate ${ }^{75} \mathrm{Se}$ into sperm selenoprotein. However, the persistence of radioactivity in caput spermatozoa might instead reflect prolonged storage of ${ }^{75} \mathrm{Se}$ in non-germinal elements (e.g. Sertoli cells) before uptake into spermatids, or its association with other proteins preceding its appearance in MCP.

\section{Incorporation of ${ }^{75}$ Se into testicular proteins}

To avoid such ambiguity and evaluate the significance of Se incorporation into MCP before midspermiogenesis, testicular fractions were analysed by SDS gel electrophoresis, after intratesticular injection of ${ }^{75}$ Se-labelled selenite at 21,28 or 90 days of age. Since preliminary experiments had indicated that uptake of ${ }^{75} \mathrm{Se}$ was relatively poor in the immature testis, the dosage was adjusted to magnify incorporation of label into testicular protein in the younger animals. The approximate levels administered per $0.1 \mathrm{~g}$ testis were $45 \mu \mathrm{Ci}$ at 21 days, $15 \mu \mathrm{Ci}$ at 28 days, and $6 \mu \mathrm{Ci}$ at 90 days of age. However, because of the high ratio of injection volume to testis volume at 21 days $(0.40-0.45)$, the efficiency of the injections at this age was only $60 \%$ as high as that at the two later ages (data not shown). The true ratio of effective dosages per gram of tissue was therefore about 9:5:2.

SDS gel electrophoresis performed on light particulate residue (r) and crude cytosol (s) fractions of testes removed for assay at $24 \mathrm{~h}$ after injection (Fig. 4) revealed dramatic increases in Se-labelled MCP in both fractions as the testes matured (see lanes a, $c$ and e, or b, $d$ and $f$ in Fig. 4b). At all ages, the labelling of MCP was heavier in the residue fraction (r) than in the cytosol (s). In fact, labelled MCP was undetectable in fraction s at 21-22 days of age (lane a) and barely detectable in this fraction at 28-29 days of age (lane c). The actual differences in selenoprotein labelling between fractions $s$ and $r$ were greater than is at first apparent, since fraction s samples contained approximately twice as much protein as did fraction $r$ samples, as indicated by Coomassie Blue staining (Fig. 4a). Similarly, the successive increments in MCP-labelling of both s and $\mathbf{r}$ between 21 and 90 days of age were even greater than indicated by Fig. 4(b), because of the decreasing dosage of tracer per gram of testis administered at the later ages (see above).

In the adult testis, MCP (Fig. 4, band 3) was the overwhelmingly preponderant radioactive polypeptide at $24 \mathrm{~h}$ after injection. In fraction s (Fig. 4, lane e), two high molecular weight species were present (bands 7 and 8), whereas in fraction $\mathrm{r}$ (Fig. 4, lane f), MCP was the only significant band in the range of $M_{\mathrm{r}} 14000-68000$. A crude residue fraction (R) (Fig. 4, lane g), ordinarily discarded when preparing $s$ and $r$, contained a unique, weakly-labelled minor component at $M_{\mathrm{r}} 28000$ (band 4) in addition to the heavy band at $M_{\mathrm{r}} 16000$ (band 3, MCP).

Comparatively little labelled MCP was present in adult testis at $5 \mathrm{~h}$ after injection. Instead, a higher molecular weight species at $M_{\mathrm{r}} 54000$ (band 6) predominated in fraction $\mathrm{r}$ (Fig. 4, lane i) and was the only labelled molecule detected in fraction s (Fig. 4, lane h). In addition, a minor component at $M_{\mathrm{r}} 47000$ (band 5) was observed in fraction $\mathrm{r}$. The heavier labelled polypeptides (bands 5 and 6 ) had virtually disappeared by $24 \mathrm{~h}$ after injection in adult testis, only a trace of band 6 being detectable (Fig. 4, lane f). Band 6 was relatively more prominent in 22-day-old testis at $24 \mathrm{~h}$ after injection (Fig. 4, fraction $r$, lane $b$ ) than at later ages (Fig. 4, lanes $d$ and $f$ ).

The testicular fractions obtained at $24 \mathrm{~h}$ after injection from 22-day-old rats possessed relatively little labelled MCP. The major radioactive species seen in fraction s was a high molecular weight component at $M_{\mathrm{r}} 58000$ (Fig. 4, band 7) and MCP was essentially undetectable. By contrast, fraction $r$ at 22 days contained significant, although relatively modest labelling of MCP (band 3), a minor polypeptide of $M_{\mathrm{r}}<14000$ (band 2), and a predominance of labelling associated with material of low molecular weight (band 1). The latter appeared to be more heterogeneous (i.e. diffuse) in gels of higher acrylamide content (e.g. 12.5\%, not shown). 


\section{Discussion}

The relatively high specific activity of caput spermatozoa $12-16$ days after intratesticular ${ }^{75} \mathrm{Se}$ injection suggests maximal rates of Se incorporation into MCP during mid-spermiogenesis (Fig. 3). The same series of data also proves that there is no Se-MCP biosynthesis after step 15, on the basis of the absence of labelling 6 days after injection. On the other hand, this type of experiment is unable to establish when the earliest synthesis of Se-MCP occurs, because of the possibility that ${ }^{75} \mathrm{Se}$ is retained by testis for long periods of time before its incorporation into MCP.

To determine when Se-MCP first appears during germ cell development, advantage was taken of the well-known schedule of germ cell development in post-natal rat testes (Clermont \& Perey, 1957). Studies of ${ }^{75} \mathrm{Se}$ labelling of testicular proteins as a function of post-natal age suggest that an initial low level of sperm selenoprotein synthesis occurs during the pachytene stage of spermatogenesis. This is indicated by the presence of modest levels of ${ }^{75} \mathrm{Se}$-labelled MCP in the $15000 \mathrm{~g}$ residue fraction ( $r$ ) of 22-day-old testis $24 \mathrm{~h}$ after administration of a relatively massive intratesticular dose of ${ }^{75} \mathrm{Se}$ (Fig. 4b, lane b). The most mature cells seen in histological sections of testis at this age (not shown) were late primary spermatocytes (i.e. late pachytene or diplotene), in accord with the observations of others (Clermont \& Perey, 1957; Knorr et al., 1970; Hodgen \& Sherins, 1973).

Since earlier germ cells do not possess germ cell-specific mitochondria (Andre, 1962; Machado de Domenech et al., 1972; DeMartino et al., 1979), the belief is strengthened that Se-MCP must first appear in pachytene spermatocytes. Its concentration then increases dramatically during further meiotic and postmeiotic development. This is supported by the decreased labelling of spermatozoa between 18 and 28 days after ${ }^{75} \mathrm{Se}$ injection (Fig. 3) and by the progressively stronger labelling of MCP at $24 \mathrm{~h}$ after injection in 29- and 90-day-old testis (Fig. 4b). The most advanced germ cells present at 29 days of age are cap-phase spermatids (Knorr et al., 1970; Hodgen \& Sherins, 1973). Round spermatids (either Golgi or cap phase) are seen in most tubules at this age (Calvin \& Turner, 1982). From comparison of ${ }^{75}$ Se-labelling of testis proteins at 22 and 29 days of age (Fig. 4b), it is evident, therefore, that the net rate of Se-MCP formation is considerably greater in early spermatids than in pachytene spermatocytes. Still higher rates of Se-MCP formation must be attained at mid-spermiogenesis (Fig. 3), thus accounting for the heavy labelling of MCP in mature testis (Fig. 4b).

Although the net rate of Se uptake into MCP in the rat seems to reach a peak midway during spermiogenesis, it appears unlikely that MCP itself is primarily synthesized at this time. $\left[{ }^{35} \mathrm{~S}\right]$ Methionine tracer studies in the mouse indicate that the highest rate of synthesis of this protein occurs in early spermatids and that a substantial level of MCP biosynthesis occurs during late meiosis (Hecht \& Kennington, 1983). The presence of MCP in mouse pachytene spermatocytes is also indicated by electrophoretic analysis of mitochondrial proteins isolated from a fraction enriched in these cells (Hecht \& Bradley, 1981). The synthesis of MCP in the mouse thus appears to coincide approximately with a burst of mitochondrial DNA synthesis, indicative of mitochondrial proliferation, during late meiosis and early spermiogenesis (Hecht \& Liem, 1984). If the same is true in the rat, then the bulk of ${ }^{75} \mathrm{Se}$ incorporation would appear to lag behind MCP biosynthesis by at least several days, thus implying the presence of Se-free MCP in immature germ cells. Simultaneous administration of two tracers (e.g. $\left[{ }^{75} \mathrm{Se}\right]$ selenite and $\left[{ }^{35} \mathrm{~S}\right]$ cysteine) might establish whether or not this is the case.

The detection of ${ }^{75}$ Se-labelled polypeptides larger than MCP (Fig. 4b) suggests that its biosynthesis may involve enzymic degradation of larger precursor molecules. Two likely precursors of MCP are the polypeptides represented by bands 5 and 6 . These species are significantly present only at $5 \mathrm{~h}$ and appear to be replaced at $24 \mathrm{~h}$ by MCP (band 3) in mature testis. A less dramatic shift of this type was noted in rats over a period of 7 days by McConnell et al. (1979), after intraperitoneal injection of ${ }^{75} \mathrm{Se}$. The intratesticular route of administration used in the present investigation has provided a more rapid and quantitative change from higher to lower molecular weight, thus suggesting very strongly that the sperm protein is derived from larger molecules. If band 6 is a 
precursor of MCP, then its persistence at $24 \mathrm{~h}$ after injection of 21-day-old testis may signify that the immature tissue is less efficient than adult testis in processing the larger polypeptide to MCP. Band 7, detectable most readily in the soluble fraction of 3-week-old testes, may also represent a precursor of MCP, although there is, as yet, no convincing evidence for this.

The prominence of ${ }^{75} \mathrm{Se}$-labelled molecules smaller than MCP in fraction $\mathrm{r}$ of 21-22-day-old testis (Fig. 4, lane b) raises the possibility that MCP is rapidly degraded by immature testis. This could account in part for the poor net incorporation of ${ }^{75} \mathrm{Se}$ into MCP at $21-22$ days of age. However, the absence of the smaller selenopeptides in fraction s and the very low overall uptake of ${ }^{75} \mathrm{Se}$ by testis at this age support the contention that a relatively slow rate of Se incorporation into protein is the primary reason for the relative deficiency of ${ }^{75} \mathrm{Se}$-labelled $\mathrm{MCP}$ at 3 weeks of age.

The mechanism of selenium incorporation into protein is a subject of active inquiry. In a variety of proteins, stably bound Se is incorporated within the polypeptide chain as selenocysteine, the analogue of cysteine in which selenium is substituted for sulphur (Stadtman, 1980; Hawkes et al., 1985; Tanaka et al., 1985). A selenocysteine-specific t-RNA has been purified from rat liver (Hawkes et al., 1982) and its selenocysteyl conjugate has been demonstrated to be an excellent precursor of the selenocysteine residue in glutathione peroxidase (Hawkes \& Tappel, 1983). However, isotope dilution studies have indicated that free selenocysteine is not an intermediate in the labelling of glutathione peroxidase by $\left[{ }^{75} \mathrm{Se}\right]$ selenite (Sunde \& Hoekstra, 1980), thus suggesting that the incorporation of $\mathrm{Se}$ into this protein is post-translational. To reconcile these seemingly conflicting findings, a more current hypothesis holds that the selenocysteine residue may arise instead by selenation of a precursor at the aminoacyl t-RNA level (Hawkes \& Tappel, 1983; Zinoni et al., 1986; Sunde \& Evenson, 1987). Perfusion of rat liver with radioactive amino acids has demonstrated that the carbon skeleton of selenocysteine in glutathione peroxidase is derived from serine (Sunde \& Evenson, 1987). Two possible pathways for the incorporation of selenium into serine have been suggested: trans-selenation from selenohomocysteine and direct selenation by selenide (Tanaka et al., 1985). Only the former has so far been demonstrable in vitro. The incorporation of selenocysteine into mammalian or bacterial proteins is encoded by the triplet, UGA, ordinarily read as a termination codon (Chambers et al., 1986; Zinoni et al., 1986). It is not yet known whether the selenocysteyl t-RNA of rat liver binds preferentially to this codon.

Since substantial synthesis of MCP or its putative high molecular weight precursors during late meiosis and early spermiogenesis (Hecht \& Kennington, 1983) appears to precede the major synthesis of Se-MCP during mid-spermiogenesis, the native presence of selenium-free MCP seems a strong possibility. The relative concentration of such a molecule could conceivably be enhanced in selenium-deficient animals. Sperm selenoprotein and other testis selenoproteins may therefore furnish a convenient system in which to examine whether post-translational incorporation of selenium into protein is a viable possibility. Alternatively, this system could be used to examine the molecular mechanisms underlying stage-dependent translational incorporation of selenocysteine into testis selenoproteins.

We thank Aram Calvin, Marjorie Smith and Cecilia Young for technical assistance and $\mathrm{Mr}$ T. M. Mathew for typing the manuscript. This research was supported by grants HD-05316 and HD-17932 from the National Institutes of Health.

\section{References}

Andre, J. (1962) Contribution a la connaissance du chondriome. Etude des ses modifications ultrastructurales pendant la spermatogenese. J. Ultrastruct. Res. Suppl. 3, 1-184.

Brown, D.G. \& Burk, R.F. (1973) Selenium retention in tissues and sperm of rats fed a Torula yeast diet. $J$. Nutr. 103, 102-108.

Calvin, H.I. (1978) Selective incorporation of selenium-
75 into a polypeptide of the rat sperm tail. $J$. exp. Zool. 204, 445-452.

Calvin, H.I. (1981) Comparative labelling of rat epididymal spermatozoa by intratesticularly administered ${ }^{65} \mathrm{ZnCl}_{2}$ and $\left[{ }^{35}\right.$ S]cysteine. J. Reprod. Fert. 61, 65-73.

Calvin, H.I. \& Turner, S.I. (1982) High levels of glutathione attained during postnatal development of rat testis. J. exp. Zool. 219, 389-393. 
Calvin, H.I., Yu, C.C. \& Bedford, J.M. (1973) Effects of epididymal maturation, zinc (II) and copper (II) on the reactive sulfhydryl content of structural elements in rat spermatozoa. Expl Cell Res. 81, 333-341.

Calvin, H.I., Wallace, E.W. \& Cooper, G.W. (1981a) Role of selenium in the organization of the mitochondrial sheath in rodent spermatozoa. In Selenium in Biology and Medicine, pp. 319-324. Eds J. E. Spallholz, J. L. Martin \& H. E. Ganther. AVI, Westport.

Calvin, H.I., Cooper, G.W. \& Wallace, E.W. (1981b) Evidence that selenium in rat sperm is associated with a cysteine-rich structural protein of the mitochrondial capsule. Gamete Res. 4, 139-149.

Chambers, I., Frampton, J., Goldfarb, P., Afiara, N., McBain, W. \& Harrison, P.R. (1986) The structure of the mouse glutathione peroxidase gene: the selenocysteine in the active site is encoded by the 'termination' codon, TGA. EMBO J. 5, 1221-1227.

Clermont, Y. \& Harvey, S.C. (1965) Duration of the cycle of the seminiferous epithelium of normal, hypophysectomized and hypophysectomized-hormone treated albino rats. Endocrinology 76, 80-89.

Clermont, Y. \& Perey, B. (1957) Quantitative study of the cell population of the seminiferous tubules in immature rats. Am. J. Anat. 100, 241-267.

DeMartino, C., Floridi, A., Marcante, M.L., Malorni, W., Scorza-Barcellona, L.P., Bellocei, M. \& Silvestrini, B. (1979) Morphological, histochemical and biochemcial studies on germ cell mitochondria of normal rats. Cell Tissue Res. 196, 1-22.

Ellman, G.L. (1959) Tissue sulfhydryl groups. Archs Biochem. Biophys. 82, 70-77.

English, H.F. \& Dym, M. (1982) The time required for materials injected into the rete testis to reach points in the caput epididymis of the rat and observations on the absorption of cationic ferritin. Ann. NY Acad. Sci. 383, 445-446.

Gunn, S.A. \& Gould, T.C. (1970) Cadmium and other mineral elements. In The Testis, Vol. 3, pp. 377-481. Eds A. D. Johnson, W. R. Gomez\& N. L. VanDemark. Academic Press, New York.

Gunn, S.A., Gould, T.C. \& Anderson, W.A.D. (1967) Incorporation of selenium into spermatogenic pathway in mice. Proc. Soc. exp. Biol. Med. 124, 1260-1293.

Hawkes, W.C. \& Tappel, A.L. (1983) In vitro synthesis of glutathione peroxidase from selenite. Translational incorporation of selenocysteine. Biochim. Biophys. Acta 739, 225-234.

Hawkes, W.C., Lyons, D.E. \& Tappel, A.L. (1982) Identification of a selenocysteine-specific aminoacyl transfer RNA from rat liver. Biochim. Biophys. Acta 699, 183-191.

Hawkes, W.C., Wilhelmsen, E.L. \& Tappel, A.L. (1985) Abundance and tissue distribution of selenocysteinecontaining proteins in the rat. J. Inorg. Biochem. 23, 77-93.

Hecht, N.B. \& Bradley, F.M. (1981) Changes in mitochondrial protein composition during testicular differentation in mouse and bull. Gamete Res. 4, 433-449.

Hecht, N.B. \& Kennington, E. (1983) Temporal synthesis of mitochondrial proteins from mouse epididymal spermatozoa. Gamete Res. 7, 289-297.

Hecht, N.B. \& Liem, H. (1984) Mitochondrial DNA is synthesized during meiosis and early spermiogenesis in the mouse. Expl Cell Res. 154, 293-297.

Hodgen, G.P. \& Sherins, R.J. (1973) Enzymes as markers of testicular growth and development in the rat. Endocrinology 93, 985-989.

Knorr, D.W., Vanha-Perttula, T. \& Lipsett, M.B. (1970) Structure and function of rat testis through pubescence. Endocrinology 86, 1298-1304.

Laemmli, U.K. (1970) Cleavage of structural proteins during the assembly of the head of bacteriophage T4. Nature, Lond. 227, 680-685.

Lillie, R.D. \& Fullmer, H.M. (1976) Histopathologic Technique and Practical Histochemistry, 4th edn. McGraw-Hill, New York.

Machado de Domenech, E., Domenech, C.E., Aoki, A. \& Blanco, A. (1972) Association of the testicular lactate dehydrogenase isozyme with a special type of mitochondria. Biol. Reprod. 6, I36-147.

McConnell, K.P., Burton, R.M., Kute, T. \& Higgins, P.J. (1979) Selenoproteins from rat testis cytosol. Biochim. Biophys. Acta 588, 113-119.

O'Farrell, P.H. (1975) High resolution two-dimensional electrophoresis of proteins. $J$. biol. Chem. 259, 4007-4021.

Otavsky, W.I. \& Drysdale, J.W. (1975) Recent staining artifacts with LKB "Ampholines" on gel isoelectric focussing. Analyt. Biochem. 65, 533-536.

Pallini, V. \& Bacci, E. (1979) Bull sperm selenium is bound to a structural protein of mitochondria. $J$. submicr. Cytol. 11, 165-170.

Pallini, V., Baccetti, B. \& Burrini, A.G. (1979) A peculiar cysteine-rich polypeptide as related to some unusual properties of mammalian sperm mitochondria. In The Spermatozoon: Maturation, Motility, Surface Properties and Comparative Aspects, pp. 141-151. Eds D. W. Fawcett \& J. M. Bedford. Urban and Schwarzenberg, Baltimore.

Pond, F.R., Tripp, M.J., Wu, A.S.H., Whanger, P.D. \& Schmitz, J.A. (1983) Incorporation of selenium-75 into semen and reproductive tissues of bulls and rams. J. Reprod. Fert. 69, 411-418.

Prohaska, J.R., Mowafy, M. \& Ganther, H.E. (1977) Interactions between cadmium, selenium and glutathione peroxidase in rat testis. Chem.-Biol. Interact. 18, 253-265.

Smith, D.G., Senger, P.L., McCutchan, J.F. \& Landa, C.A. (1979) Selenium and glutathione peroxidase distribution in bovine semen and selenium- 75 retention by the tissues of the reproductive tract in the bull. Biol. Reprod. 20, 377-383.

Stadtman, T. (1980) Selenium-dependent enzymes. Ann. Rev. Biochem. 49: 93-110.

Sunde, R.A. \& Evenson, J.K. (1987) Serine incorporation into the selenocysteine moiety of glutathione peroxidase. J. biol. chem. 262, 933-937.

Sunde, R.A. \& Hoekstra, W.G. (1980) Incorporation of selenium from selenite and selenocystine into glutathione peroxidase in the isolated perfused rat liver. Biochem. Biophys. Res. Commun. 93, 1181-1188.

Tanaka, H., Esaki, N. \& Soda, K. (1985) Selenocysteine metabolism in mammals. Curr. Top. Cell Regul. 27, 487-495.

Wallace, E., Calvin, H.I. \& Cooper, G.W. (1983a) Progressive defects observed in mouse sperm during the course of three generations of selenium deficiency. Gamete Res. 4, 377-387. 
Wallace, E., Cooper, G.W. \& Calvin, H.I. (1983b) Effects of selenium deficiency on the shape and arrangement of rodent sperm mitochondria. Gamete Res. 4, 389-399.

Wu, S.H., Oldfield, J.E. \& Whanger, P.D. (1973) Effects of selenium, vitamin $\mathrm{E}$, and antioxidants on testicular function in rats. Biol. Reprod. 8, 625-629.

Wu, A.S.H., Oldfield, J.E., Shull, L.R. \& Cheeke, P.R. (1979) Specific effect of selenium deficiency on rat sperm. Biol. Reprod. 20, 793-798.
Zinoni, F., Birkmann, A., Stadtman, T.C. \& Bock, A. (1986) Nucleotide sequence and expression of the selenocysteine-containing polypeptide of formate dehydrogenase (formate-hydrogen-lyase-linked) from Escherichia coli. Proc. natn. Acad. Sci. U.S.A. 83, $4650-4654$.

Received 20 October 1986 